\title{
How Integrated are Finns in the Swedish Labour Market? Outcomes of Free Labour Mobility ${ }^{1}$
}

\author{
Jan Saarela* and Dan-Olof Rooth**
}

\begin{abstract}
Due to the agreement of a common Nordic labour market, Finns have for several decades constituted the largest immigrant group in Sweden. However, there have been few studies explicitly concerned with how well they are integrated in the labour market. This paper attempts to fill part of this gap by studying how they succeeded before and after the economic crisis in the 1990s. Employment levels and earnings of Finnish immigrants in prime working ages are compared with those of native Swedes by utilizing matched cross sections of the total population from 1990 and 2001. We aim to see how much of any differential can be attributed to simple background factors such as age, gender, educational level, and county of residence. Our findings reveal that earnings and employment levels of Finnish males are about 10 per cent lower than those of native Swedes, and that this performance gap tends to have become wider over time. There is, however, substantial variation across immigrant cohorts, and differentials in educational levels play a significant role only with regard to the earnings gap. In contrast with the males, Finnish females tend to be better integrated, as their labour market outcomes are very similar to those of native Swedes.
\end{abstract}

\footnotetext{
* Åbo Akademi University, Vasa, Finland.

** Department of Economics, Kalmar University, Sweden.
} 


\section{INTRODUCTION}

Two primary objectives of Swedish economic policy are full employment and income equality across subgroups of the population (Ekberg, 2004). With respect to immigrants, these goals are to be fulfilled by general social and welfare policies, but for their realization public authorities are obliged to use measures deemed necessary. The labour market in Sweden is characterized by a system that secures basic income for all people, comprehensive regulation to protect workers' rights, and extensive collective agreements. The level of the minimum wage, for instance, is negotiated centrally. Newly arrived immigrants in Sweden are consequently expected to gain economic security as well as decent pay.

There are also policies directed specifically towards the immigrant population. The most important features, as formulated by the Swedish Parliament, are the principles of equality, freedom of choice, and cooperation. They aim to ease the adaptation process of the immigrant, but also to facilitate maintenance of the immigrant's home language and cultural heritage. In 1968, equality was laid down as a primary principle, implying that immigrants should have the same rights and obligations as Swedish citizens, and the same opportunities to provide for their needs and interests. The other two principles, which were formulated in 1975, disclaim "assimilation" in terms of acquiring Swedish cultural identity and neglecting one's own cultural heritage. The degree of integration is instead left to the immigrant to decide. Freedom of choice means that the immigrant is encouraged to choose the degree and extent to which she wants to acquire Swedish cultural identity. It should, however, not be interpreted as a right not to learn Swedish or to disassociate oneself from the community. Cooperation means that there should be mutual and comprehensive collaboration between immigrants and native Swedes with regard to issues of common interest, and immigrants should consequently have the opportunity to share responsibility for the development of society.

The three principles were confirmed anew in 1986. They have not received much criticism, but the methods used to accomplish them have been questioned. The labour market situation of immigrants during past years clearly shows that the policy programmes have not produced satisfactory results with respect to equality in relation to native Swedes (see e.g. Rooth and Ekberg, 2003). One reason is obviously the change in economic policy at the beginning of the 1990s, which was interrelated with a severe downturn of the economy that lasted for almost a decade. At the end of the 1980s, the Swedish economy was experiencing an economic boom with very high employment levels and correspondingly low unemployment rates (below 2\%). Employment levels began to fall at the very beginning of the 1990s and the unemployment rate reached the unprecedented 
level of 10 per cent in 1993. It was still as high as 6 per cent in 1999, when the employment rate was below 75 per cent (Figure 1). These are figures that from a historical perspective should be considered fairly high.

\section{FIGURE 1}

EMPLOYMENT RATE IN SWEDEN, AGES 16-64 YEARS, 1983-2003

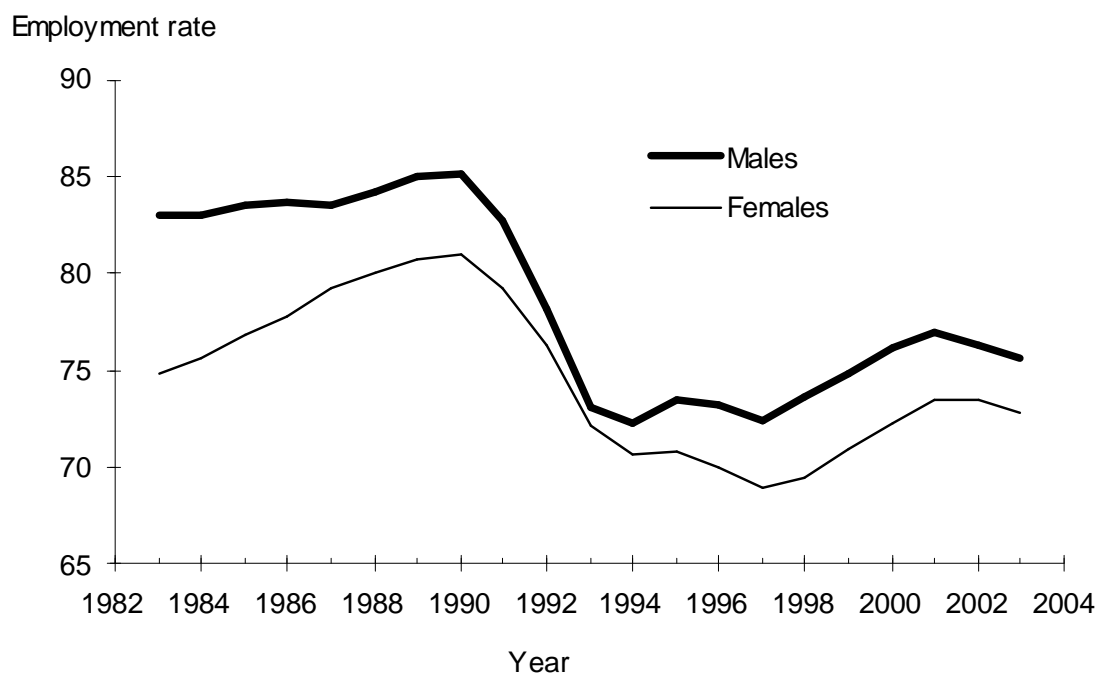

Source: Statistics Sweden (2004).

The topic of this paper is to analyse the labour market integration of the largest immigrant group in Sweden, the Finns, during the turbulent decade of the 1990s. Specifically, we aim to study the employment and earnings of people in prime working ages, who we observed in 1990 and in 2001. They arrived in Sweden at a time when the demand for labour was high, but were later faced with radically different labour market conditions. Our purpose is, therefore, to study how Finnish immigrants have succeeded in the Swedish labour market as compared with native Swedes during such a "worst possible" scenario. Of specific interest is to study how much of any differential between the two population groups can be attributed to the structural factors of age, gender, educational level, and county of residence.

\section{FINNISH IMMIGRANTS IN SWEDEN}

Finnish immigrants in Sweden are interesting for two primary reasons. Firstly, emigration from Finland has played a central role in the development of the 
Swedish economy ever since the 1950s, owing to the demand for labour needed in Swedish industry. The geographical closeness and similarities in working life, institutions, and culture also promoted migration flows (Korkiasaari and Söderling, 1998; Finnäs, 2003; Hedberg and Kepsu, 2003). More than half a million Finns moved to Sweden over a 50-year period, which amounts to one-tenth of the current Finnish population. However, more than half returned to Finland after a few years stay in Sweden. Economic upswings in Sweden and structural changes in Finland induced peaks in migration at the beginning of the 1950s, in the middle of the 1960s, and in the very early 1970s. When Swedish industry's demand for labour declined and the economic climate in Finland improved in the 1980s, net migration from Finland to Sweden stopped. At the end of the millennium, Sweden accounted for less than one-third of all migration from Finland. In spite of the fact that total immigration to Sweden has changed in character notably during the past two decades, with a shift from labour migrants to refugees and other asylum seekers, Finns still constitute the largest immigrant group in the country. At the end of 2001, there were almost 200,000 persons residing in Sweden who were born in Finland. Surprisingly few studies have, however, been concerned with the situation of this large group of immigrants in the Swedish labour market. This paper attempts to fill part of that gap.

The situation of Finnish immigrants in Sweden is also of broader interest. It may provide important lessons for the policy of labour mobility in the whole European community, because circumstances of 50 years ago resemble those prevailing at present in the European Union. Ever since 1954, citizens of Finland, Sweden, Norway, Denmark, and Iceland have been free to move between the countries. This agreement of a common Nordic labour market implied free mobility of labour with non-perfect transferable labour market skills, without the need for residence or work permits. The question of how integrated Finns are in the Swedish labour market may therefore provide gainful insights into the long-term consequences of free labour mobility. Relative migration flows between Finland and Sweden have been much larger than current ones at the European level, however.

\section{PREVIOUS FINDINGS}

Employment and income opportunities of immigrants have received a lot of attention in the international literature and have been the focus of lively scientific debate. ${ }^{2}$ From an empirical point of view, there are two principle reasons behind potential variation in labour market performance between immigrants and natives. Firstly, the groups may differ in observable characteristics that promote 
outcomes. This set of explanations can be related to intrinsic differentials in productivity between population groups, to selective in-migration and selective out-migration, and to variation in quality between immigrant cohorts. Secondly, immigrants and natives may differ in returns to their characteristics. This can be the result of institutional arrangements and barriers (discrimination), individual norms and lifestyles, and other latent unobservable factors (see Borjas, 1987, 1994). We focus on the role of the first set of explanations. It should, though, be emphasized that we do not aim at finding exhaustive answers to potential differences in labour market outcomes between Finnish immigrants and native Swedes. Our approach is rather to describe and discuss the situation in an explorative manner.

Studies of immigrants' integration in Sweden show that, in the 1950s, 1960s, and the early 1970s, labour force participation was higher and unemployment lower than of native Swedes. The hourly wage rate was about the same in similar occupations (Wadensjö, 1973; Ohlsson, 1975; Ekberg, 1983). This picture changed during the 1970s, with decreasing labour force participation rates, increasing unemployment rates, and lower relative incomes of several immigrant groups (Scott, 1999). Aguilar and Gustafsson (1991) found that immigrants who arrived in Sweden in 1969 caught up with the earnings of native Swedes, but that was not the case for those who arrived in 1974. Bantekas (1992) and Wadensjö (1994) reached the conclusion that immigrants had about the same hourly wage rate as native Swedes in 1974 and 1981, but that it was lower in 1991. The pattern of deteriorating labour market positions for latearrived immigrant cohorts is confirmed in the studies by Bevelander (1995), Bevelander and Skyt Nielsen (2001), and Scott (1999), which emphasize structural changes within the Swedish economy as a major determinant of the labour market outcomes of immigrants during the period 1970 to 1990. It seems that the labour market situation for immigrants in Sweden has worsened even further during the 1990s. Ekberg and Andersson (1995) report employment rates for certain immigrant groups that are very low. The situation for Finns also seemed to have worsened. In 1969, Finns in Sweden had relative employment rates, adjusted for age and gender, that were 20 per cent higher than those of native Swedes. In 1999, they were 7 per cent lower (Gustafsson et al., 2004).

In many previous analyses of immigrants in the Swedish labour market, Finns have been assigned to a group consisting of immigrants from all Nordic countries (Edin et al., 2000; Pekkari, 2000; Bevelander and Skyt Nielsen, 2001). It is doubtful whether such results can be seen as representative for Finnish immigrants, as there is substantial heterogeneity within the group originating from the Nordic countries. This is supported by recent findings, which suggest that immigrants from the Nordic countries differ in employment rates, relative 
income, and labour force participation (Gustafsson et al., 2004; Gustafsson and Österberg, 2004).

Empirical analyses that have been explicitly concerned with Finns in the Swedish labour market are thus relatively rare. The overall picture they provide is that the employment and earnings levels of Finns in Sweden are lower than those of native Swedes. This is perhaps not too surprising, considering the disadvantages an immigrant group faces when trying to adapt to a new labour market. Similar to the case with other immigrant groups in Sweden, differences in observable individual characteristics did not seem to be an exhaustive explanation for the relatively poor labour market performance of Finns. Since a large number of Finnish immigrants traditionally have consisted of unskilled labour, it is evident that part of the variation was due to socio-economic differences. However, it seemed to be mainly Finnish male immigrants who performed worse than their Swedish counterparts. At least in some respects, Finnish females tended to have even a better position than Swedish females.

The main results of Ekberg's pioneering works in this field $(1991,1994)$, which studied the situation in the 1970s and 1980s, were that income and employment rates of Finnish males were lower than those of native Swedes. Finnish females, on the other hand, had both higher employment rates and somewhat higher income levels than their Swedish counterparts. Ekberg also studied the cohort of people who immigrated to Sweden between 1971 and 1975, and followed them over time every fifth year until 1985 . Specifically among males, he found that the socio-economic and income mobility of Finns was slower than among Swedes. It was argued that this could be interrelated with the fact that many Finns originated from the countryside and therefore lacked industrial experience. It should be noted, though, that immigrants arriving in Sweden after 1975 were not included in the analysis. The relatively low employment rates of the Finns were assumed to be related to their poorer health, as they had higher mortality and retirement rates than native Swedes (see Ekberg, 1996; Gustafsson and Österberg, 2004).

Studies using survey data (Leiniö, 1979, 1984), which also reflected the situation in the 1970s and 1980s, arrived at fairly similar conclusions to Ekberg. Still, those findings should be seen in the light of small sample sizes and potentially selective response. The same arguments naturally apply to more recent research using survey data (Statistics Sweden, 2002). While being rich in detail and extensive in approach, the empirical analyses pool information for both genders and for several observation years, which is an approach that may lead to ambiguous results, considering that labour market prospects tend to have changed over time and that there could be gender differences in both labour market outcomes and economic integration. 


\section{DATA AND METHODOLOGY}

The data to be utilized in this paper are based on two cross sections, one at the end of 1990 and the other at the end of 2001, for the total population residing in Sweden. They are matched at the individual level, and constructed by integrating records from the Swedish National Labour Market Board and Statistics Sweden. The data contain information on individuals' employment status, annual earnings, age, gender, education level, country of birth, county of residence, and the most recent year of immigration to Sweden if the person is foreignborn. The concept employment refers to whether a person was employed for at least one hour per week in October in the 1990 data and in November in the 2001 data. Annual earnings are all in 2001 prices.

Our analyses focus on Finns and Swedes in prime working ages. The people under study are thus those born 1940 to 1954 and 1951 to 1965, who were aged 36 to 50 years in 1990 and 2001, respectively. A person is categorized as being a Finn if he or she was born in Finland, whereas a Swede is identified as being born in Sweden to Swedish-born parents. Second-generation Finns in Sweden, that is, people with at least one parent born in Finland, are excluded from the analysis. ${ }^{3}$ As we are interested in the labour market situation of the whole group of Finns in these ages, individuals are included regardless of the age they immigrated to Sweden. ${ }^{4}$

To simplify practical matters, the part of the data representing Swedes is a 10 per cent random sample of those residing in Sweden at the end of both 1990 and 2001, born in the same years as the Finns. We do not consequently address issues related to the emigration and return migration of native Swedes. The data on the Finns constitute the total population residing in Sweden at the end of 1990 and at the end of 2001.

From the data, it is not known whether a person who is lost between years in the data has emigrated or died. Most attrition is evidently due to emigration; on the basis of life tables for Sweden, we approximate the proportion of deaths to be 0.25 for males and 0.33 for females. We will refer to attrition, i.e. to people who resided in Sweden in 1990 but not in 2001, as "return migrants" because the majority of these obviously have returned to Finland. Still, it should be kept in mind that some of them have died between the two periods. "In-migrants" are those who were resident in Sweden in 2001, but not in 1990. Later, however, we attempt to study integration in a more long-term perspective and include people in the analysis only if they resided in Sweden in both of the years. In that case, Finns who have left Sweden after 1990 and those who immigrated to Sweden after 1990 are consequently excluded. 
The statistical analyses focus on exploring whether and how differences between Finns and native Swedes in employment levels and earnings have changed over time, and how much of any such differentials can be attributed to the simple structural factors available from data. This implies that we decompose employment and earnings differentials between the two population groups, based on the standard methodology developed by Neumark (1988) and Oaxaca and Ransom (1994). Estimation results of employment and earnings regressions that underlie these decompositions are, for the sake of brevity, not displayed throughout the text (but are available from the authors upon request). These estimates are generally in line with corresponding ones found elsewhere in the literature.

For simplicity, and because the standard decomposition technique cannot be used directly if coefficients are from a non-linear model (Dustmann and Fabbri, 2003), ${ }^{5}$ we use estimates from a linear probability model in the decomposition of employment. The results would be very similar if logit or probit models were applied, however. Earnings regressions use the standard OLS model.

In the results reported we indicate whether a variable significantly (at the 5\% level) contributes to the differential in outcome between Finns and Swedes, i.e. whether there is a significant reduction in the gap in labour market performance between the two groups when the impact of that variable is accounted for.

In the context of decomposition, unobserved heterogeneity is generally viewed as the part of the between-group differential in outcome that cannot be attributed to between-group variation in the distribution of control variables. This remaining differential is then due to differences in the returns to control variables (differences in coefficients). Naturally, the residual could equally well be viewed as caused by discrimination, or by anything else that cannot be directly observed from the data.

\section{DESCRIPTIVE STATISTICS}

At the aggregate level, Finns in Sweden have substantially lower employment rates than native Swedes. This is illustrated in Table 1, which gives the employment rate of people aged 36 to 50 years in 1990 and in 2001, respectively. Whereas 94 per cent of all Swedish males were employed in 1990, the number was only 84 per cent for Finnish males. For females the corresponding numbers were 92 per cent and 86 per cent, respectively, and the between-group differential thus smaller than among males. In 2001, overall employment levels were much lower than in 1990, but the gap between Finns and Swedes had 
increased further. It should also be recognized that employment levels of Finns who resided in Sweden in both years were much higher than among Finns categorized as return-migrants and in-migrants. The employment level in 1990 of Finnish males who resided in Sweden only in 1990, for instance, was 64 per cent, as compared with 87 per cent for those who resided in Sweden in both years.

TABLE 1

EMPLOYMENT RATE, AGES 36-50 YEARS OLD

\begin{tabular}{|l|c|c|}
\hline & Males & Females \\
\hline In 1990 & & \\
Swedes & 94.1 & 91.7 \\
Finns & 83.8 & 86.5 \\
$\quad$ Not return migrants & 86.9 & 87.7 \\
Return migrants & 64.2 & 70.0 \\
In 2001 & & \\
Swedes & 88.7 & 86.3 \\
Finns & 74.3 & 79.3 \\
$\quad$ Not in-migrants & 75.5 & 79.8 \\
In-migrants & 55.7 & 70.2 \\
\hline
\end{tabular}

Also with regard to annual earnings, Finnish males seem to be in a less favourable position than Swedish males. Table 2 gives the median earner in 1,000 SEK (about 110 Euros) for people aged 36 to 50 years with positive annual earnings in 1990 and in 2001, respectively. The median Finnish male is found at 217 in 1990, as compared with 239 for the Swedish one. In 2001, the corresponding numbers were 241 and 257, and the gap thus about the same as in 1990. As can be seen in Figure 2, which provides a more detailed picture of the distribution of positive annual earnings in 1990, the great part of both male Finns and male Swedes had earnings in the range 150 to 300 . Still, there are more Finns in the lower part and correspondingly more Swedes in the upper part of the earnings distribution. In 2001 (Figure 3), overall earnings dispersion was greater than in 1990, but differences between population groups persisted.

For females the pattern is different, as Finns tend to earn slightly more than Swedes. The median Finnish female with positive earnings is found at 171 in 1990, as compared with 165 for Swedish females. In 2001, the earnings advantage of Finnish females had decreased slightly and the distribution was fairly similar to that of Swedish females. 
TABLE 2

MEDIAN POSITIVE ANNUAL EARNINGS (1,000 SEK), AGES 36-50 YEARS

\begin{tabular}{|l|c|c|}
\hline & Males & Females \\
\hline In 1990: & & \\
Swedes & 239 & 165 \\
Finns & 217 & 171 \\
Not return migrants & 221 & 172 \\
Return migrants & 182 & 158 \\
In 2001: & 257 & \\
Swedes & 241 & 189 \\
Finns & 242 & 193 \\
Not in-migrants & 226 & 193 \\
In-migrants & & 179 \\
\hline
\end{tabular}

FIGURE 2

DISTRIBUTION OF POSITIVE ANNUAL EARNINGS IN 1990, AGES 36-50 YEARS

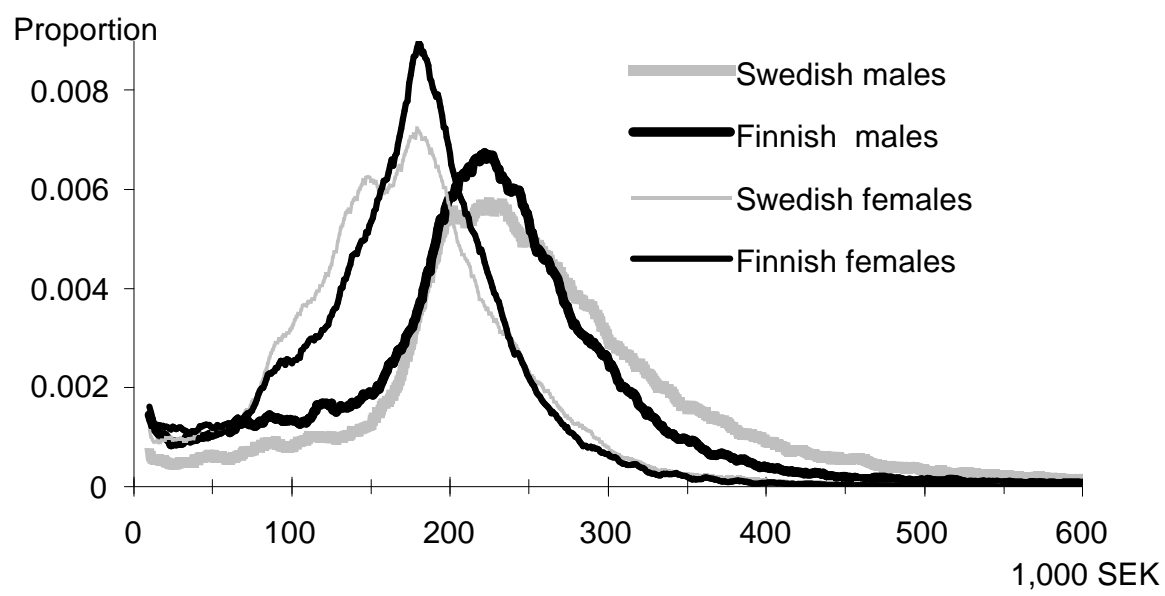

Notes: The description refers to a ten-point moving average. The proportion of people with zero earnings and earnings above 600,000 SEK, respectively, is 0.028 and 0.017 among Swedish males, 0.082 and 0.005 among Finnish males, 0.043 and 0.001 among Swedish females, and 0.075 and 0.000 among Finnish females. 


\section{FIGURE 3}

DISTRIBUTION OF POSITIVE ANNUAL EARNINGS IN 2001, AGES 36-50 YEARS

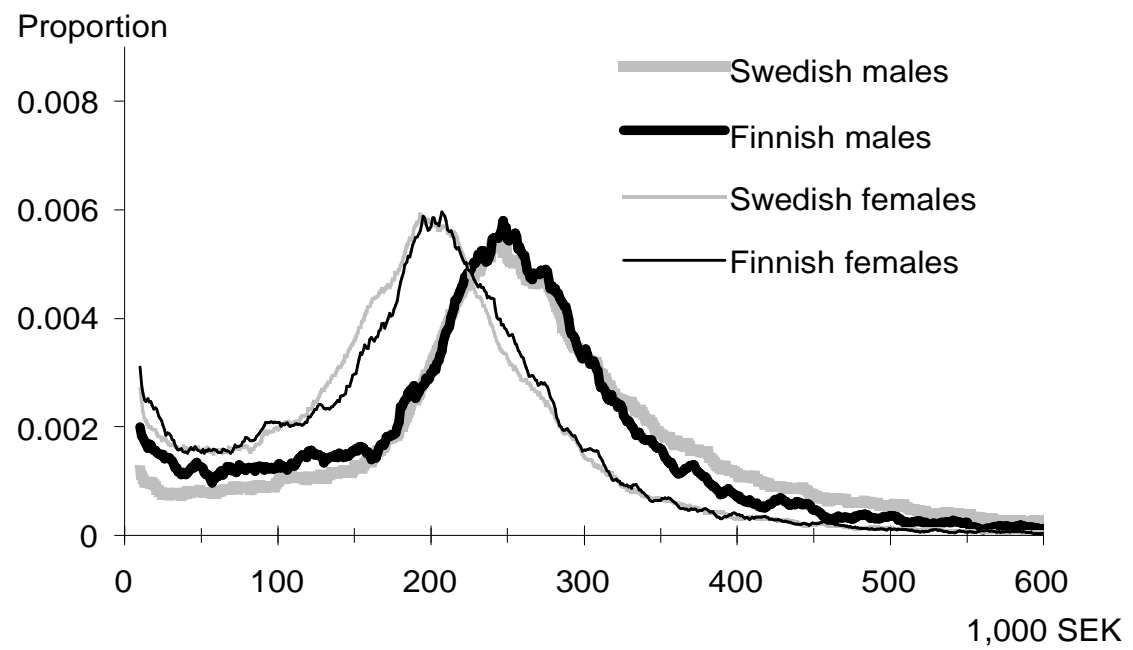

Notes: The description refers to a ten-point moving average. The proportion of people with zero earnings and earnings above 600,000 SEK, respectively, is 0.076 and 0.038 among Swedish males, 0.195 and 0.017 among Finnish males, 0.085 and 0.006 among Swedish females, and 0.148 and 0.004 among Finnish males.

Similar to the case with employment levels, earnings of return-migrants and inmigrants are substantially lower than of Finns who have resided in Sweden both in 1990 and in 2001. For instance, the median male Finnish return-migrant earned 182,000 SEK in 1990, as compared with 221,000 SEK for one who lived in Sweden both in 1990 and in 2001.

Part of the differential in employment and earnings between Finns and native Swedes can consequently be attributed to changes in the composition of the Finnish immigrant population in Sweden. Since the data are not informative enough to separate people who return-migrate from those who die, it is plausible that "return migrants" have poor outcomes due to severe latent health problems. They could also constitute a non-random group with regard to return migration, which is an argument that tends to be supported by the data. Table 3 shows that return-migrants are overrepresented among those residing in the Stockholm area, among those who immigrated after 1980, and among those with unknown educational level. Also the in-migrant group appears to deviate, as relatively many of them have high, but also unknown, levels of education. Almost half have settled in the Stockholm area. 
TABLE 3A

SOME DESCRIPTIVE STATISTICS OF BACKGROUND

VARIABLES IN THE DATA (\%)

\begin{tabular}{|c|c|c|c|c|c|c|}
\hline & \multicolumn{6}{|c|}{ Males } \\
\hline & \multicolumn{3}{|c|}{ Born 1940-1954 } & \multicolumn{3}{|c|}{ Born 1951-1965 } \\
\hline & Swedes & $\begin{array}{l}\text { Finns, not } \\
\text { return } \\
\text { migrants }\end{array}$ & $\begin{array}{l}\text { Finns, } \\
\text { return } \\
\text { migrants }\end{array}$ & Swedes & $\begin{array}{l}\text { Finns, } \\
\text { not in- } \\
\text { migrants }\end{array}$ & $\begin{array}{c}\text { Finns, } \\
\text { in- } \\
\text { migrants }\end{array}$ \\
\hline Age in years & & & & & & \\
\hline $36-44$ & 63 & 62 & 60 & 60 & 55 & 65 \\
\hline $45-50$ & 37 & 38 & 40 & 40 & 45 & 35 \\
\hline $\begin{array}{l}\text { Educational } \\
\text { level }\end{array}$ & & & & & & \\
\hline Basic & 30 & 44 & 44 & 19 & 30 & 17 \\
\hline $\begin{array}{l}2 \text {-year } \\
\text { vocational }\end{array}$ & 27 & 32 & 18 & 39 & 44 & 16 \\
\hline $\begin{array}{l}\text { 3-year } \\
\text { vocational }\end{array}$ & 16 & 11 & 7 & 12 & 10 & 9 \\
\hline Undergraduate & 10 & 5 & 2 & 12 & 7 & 22 \\
\hline Graduate & 17 & 7 & 6 & 17 & 8 & 8 \\
\hline Unknown & 0 & 1 & 23 & 0 & 1 & 28 \\
\hline County & & & & & & \\
\hline Stockholm & 17 & 32 & 39 & 18 & 34 & 48 \\
\hline $\begin{array}{l}\text { Västra } \\
\text { Götaland }\end{array}$ & 17 & 17 & 20 & 17 & 16 & 11 \\
\hline $\begin{array}{l}\text { Other } \\
\text { Immigration } \\
\text { year }\end{array}$ & 66 & 51 & 41 & 65 & 50 & 41 \\
\hline-1967 & - & 44 & 24 & - & 35 & - \\
\hline 1968-1972 & - & 26 & 22 & - & 24 & - \\
\hline 1973-1980 & - & 21 & 29 & - & 27 & - \\
\hline $1981-1990$ & - & 9 & 25 & - & 14 & - \\
\hline $\mathrm{n}$ & 66,565 & 31,179 & 4,928 & 66,682 & 23,931 & 1,504 \\
\hline
\end{tabular}

Notes: "Finns not return-migrants" and "Finns not in-migrants" refer to people residing in Sweden both in 1990 and in 2001, "Finns return-migrants" to those residing in Sweden in 1990 but not in 2001, and "Finns in-migrants" to those residing in Sweden in 2001 but not in 1990. 
TABLE 3B

SOME DESCRIPTIVE STATISTICS OF BACKGROUND VARIABLES IN THE DATA (\%)

\begin{tabular}{|c|c|c|c|c|c|c|}
\hline & \multicolumn{6}{|c|}{ Females } \\
\hline & \multicolumn{3}{|c|}{ Born 1940-1954 } & \multicolumn{3}{|c|}{ Born 1951-1965 } \\
\hline & Swedes & $\begin{array}{c}\text { Finns, not } \\
\text { return } \\
\text { migrants }\end{array}$ & $\begin{array}{l}\text { Finns, } \\
\text { return } \\
\text { migrants }\end{array}$ & Swedes & $\begin{array}{l}\text { Finns, } \\
\text { not in- } \\
\text { migrants }\end{array}$ & $\begin{array}{l}\text { Finns, } \\
\text { in- } \\
\text { migrants }\end{array}$ \\
\hline Age in years & & & & & & \\
\hline $36-44$ & 63 & 64 & 64 & 60 & 52 & 71 \\
\hline $45-50$ & 37 & 36 & 36 & 40 & 48 & 29 \\
\hline $\begin{array}{l}\text { Educational } \\
\text { level }\end{array}$ & & & & & & \\
\hline Basic & 23 & 34 & 42 & 12 & 21 & 12 \\
\hline $\begin{array}{l}2 \text {-year } \\
\text { vocational }\end{array}$ & 37 & 36 & 22 & 39 & 39 & 15 \\
\hline $\begin{array}{l}3 \text {-year } \\
\text { vocational }\end{array}$ & 8 & 8 & 7 & 13 & 12 & 10 \\
\hline Undergraduate & 4 & 3 & 3 & 6 & 5 & 33 \\
\hline Graduate & 28 & 19 & 15 & 30 & 22 & 17 \\
\hline Unknown & 0 & 0 & 12 & 0 & 0 & 13 \\
\hline County & & & & & & \\
\hline Stockholm & 18 & 38 & 44 & 19 & 39 & 49 \\
\hline $\begin{array}{l}\text { Västra } \\
\text { Götaland }\end{array}$ & 16 & 15 & 16 & 17 & 14 & 9 \\
\hline Other & 66 & 47 & 40 & 64 & 47 & 42 \\
\hline $\begin{array}{l}\text { Immigration } \\
\text { year }\end{array}$ & & & & & & \\
\hline-1967 & - & 46 & 30 & - & 28 & - \\
\hline 1968-1972 & - & 31 & 23 & - & 25 & - \\
\hline $1973-1980$ & - & 18 & 25 & - & 31 & - \\
\hline $1981-1990$ & - & 5 & 22 & - & 16 & - \\
\hline $\mathrm{n}$ & 64,719 & 41,750 & 2,991 & 63,620 & 30,421 & 1,595 \\
\hline
\end{tabular}

Notes: See Table 3A. 
To do full justice to the question of long-term integration of Finns in Sweden, it is important to attempt to compare like with like. In all the analysis to follow, we therefore compare Finns who resided in Sweden both in 1990 and in 2001 with similar Swedes. People who left Sweden after 1990 and those who entered Sweden after 1990 are consequently excluded from further analysis. Obviously, this approach to some extent reduces problems associated with unobserved heterogeneity and selective migration, as it avoids including the group of Finns who stayed only a few years in Sweden. They may have had different motivations for migration than those who stayed more permanently (see Dustmann, 2000). ${ }^{6}$

It is also essential to know how a person's situation has evolved over time. This is accomplishable with the present data, as they are matched at the individual level. Table 4 gives the employment rate in 2001 according to the same persons' employment status in 1990 for people born between 1940 and 1954 (aged 36-50 years in 1990) and between 1951 and 1965 (aged 36-50 years in 2001), respectively. It shows that employment propensity is substantially lower among Finns than among Swedes, especially among people who were not employed in 1990. For instance, less than 25 per cent of the Finns in the older birth cohort who were not employed in 1990 were employed in 2001, as compared with barely 40 per cent of the Swedes. Also, in the younger birth cohort there is a large Finnish-Swedish differential, in spite of the fact that overall employment levels are substantially higher than in the older one.

TABLE 4

EMPLOYMENT RATE IN 2001 BY EMPLOYMENT STATUS IN 1990

\begin{tabular}{|l|cccc|cccc|}
\hline & \multicolumn{3}{|c|}{ Males employed in 1990 } & \multicolumn{4}{c|}{ Females employed in 1990 } \\
& \multicolumn{2}{|c|}{ Finns } & \multicolumn{2}{c|}{ Swedes } & \multicolumn{2}{c|}{ Finns } & \multicolumn{2}{c|}{$\begin{array}{c}\text { Swedes } \\
\end{array}$} \\
& Yes & No & Yes & No & Yes & No & Yes & No \\
\hline Born 1940-1954 & 73.8 & 22.8 & 86.2 & 37.8 & 75.9 & 24.7 & 85.4 & 38.9 \\
Born 1951-1965 & 82.0 & 37.3 & 91.3 & 58.2 & 84.2 & 49.6 & 89.0 & 62.6 \\
\hline
\end{tabular}

Note: The description refers to people residing in Sweden both in 1990 and in 2001.

Earnings mobility is described in Table 5, which gives the median change in annual individuals' earnings from 1990 to 2001 in cohorts born between 1940 and 1954, and 1951 and 1965, respectively. The description is, on the one hand, for people with positive annual earnings in both years and, on the other hand, for those with annual earnings above 36,000 SEK in both years. We can see that the earnings mobility of Finns has been substantially lower than of native Swedes. 
Finnish males in the younger birth cohort tend to be in a specifically poor position. The median Finnish male born between 1951 and 1965 with earnings above 36,000 SEK, for example, experiences a 36,000 SEK earnings increase, as compared with 45,000 SEK for the median Swedish male.

In the statistical analysis of earnings to follow, we focus on people with annual earnings above 36,000 SEK, because this threshold (and the age restriction) helps to exclude shorter employment spells and part-time jobs. Hence it results in estimates that are closer to those expected for hourly wages than if using all positive earnings, as higher earnings are more likely to be based on similar amounts of time worked (see Antelius and Björklund, 2000).

TABLE 5

MEDIAN CHANGE IN IND IVIDUAL ANNUAL EARNINGS (1,000 SEK) FROM 1990 TO 2001

\begin{tabular}{|l|cc|cc|}
\hline & \multicolumn{2}{|c|}{$>0$} & \multicolumn{2}{c|}{$>36,000$ SEK } \\
& Finns & Swedes & Finns & Swedes \\
\hline Males & & & & \\
Born 1940-1954 & 16 & 21 & 20 & 45 \\
Born 1951-1965 & 35 & 44 & 36 & 34 \\
Females & & & & 47 \\
Born 1940-1954 & 24 & 31 & 29 & 45 \\
Born 1951-1965 & 41 & 44 & 45 & \\
\hline
\end{tabular}

Notes: The description refers to people residing in Sweden both in 1990 and in 2001; " $>0$ " is for people with positive annual earnings both years and ">36,000 SEK" for those with over 36,000 SEK both years.

As shown in Table 3, there are obvious reasons to explore what remains of the above depicted differences in employment and earnings having accounted for the impact of background factors. Finns are lower-educated and older than native Swedes, and a higher proportion of them live in the county of Stockholm.

\section{RESULTS}

\section{Employment differentials}

To allow for behavioural differences in employment propensity we estimated separate regressions across genders, population groups, and cross section years 
(results not shown). The impact of background variables turned out as expected: employment probability was found increasing in educational level, to peak at ages just more than 40 years, and to vary according to the regional economic opportunities of each county. In practically all socio-demographic subgroups there was an employment advantage for native Swedes as compared with Finnish immigrants, which was larger in males than in females. The only exceptions were higher-educated Finnish females, who had somewhat higher employment levels than their Swedish counterparts. In ages 36 to 50 years, the only groups of Finns who had managed to maintain their employment position between 1990 and 2001 were also those with undergraduate or graduate education.

The contribution of background variables on the Finnish-Swedish employment differential is obtained by performing decompositions by gender, observation year, and birth cohort. The results (Table 6) show that distributional differences in background variables contribute to a fairly small part of the employment gap. Educational level is still the single factor most important, attributing to between 10 and 34 per cent, depending on the subgroup under study. For each gender, the highest differential is found in 2001 for people born between 1940 and 1954 . As these people were 47 to 61 years old at that time, this is obviously interrelated with higher early retirement rates of the Finns (see Ekberg, 1996; Gustafsson and Österberg, 2004). A closer investigation of the data also revealed that the difference in employment rates between Finns and Swedes was particularly marked in people born during the first half of the 1940s, i.e. among those who may be entitled to early retirement pension.

The substantial decline in the relative employment position of Finns from 1990 to 2001 could, however, also be dependent on employment experience and the year at which they have arrived in Sweden. As overall employment levels were exceptionally high in 1990, people not in employment at that time are likely to be a very selective group in the labour market. The proportion of Finns found in this category is also larger than the corresponding proportion among Swedes (Table 4).

The year of immigration, on the other hand, may reflect the degree of integration on the Swedish labour market, as people having lived longer in the new country have had more time to adapt to new circumstances. Still, it may also proxy differences in immigrant cohort quality, if those having arrived at a certain time are equipped with characteristics that make them less, or more, competitive in the labour market than those having arrived at any other time. $^{7}$ 
TABLE 6

EMPLOYMENT DIFFERENTIAL BETWEEN FINNS AND SWEDES BY GENDER, OBSERVATION YEAR AND BIRTH COHORT, DECOMPOSITION RESULTS

\begin{tabular}{|c|c|c|c|c|c|c|c|c|}
\hline & \multicolumn{4}{|c|}{ Males } & \multicolumn{4}{|c|}{ Females } \\
\hline & \multicolumn{2}{|c|}{1990} & \multicolumn{2}{|c|}{2001} & \multicolumn{2}{|c|}{1990} & \multicolumn{2}{|c|}{2001} \\
\hline & $\begin{array}{l}\text { Born } \\
1940- \\
1954\end{array}$ & $\begin{array}{c}\text { Born } \\
1951- \\
1965\end{array}$ & $\begin{array}{c}\text { Born } \\
1940- \\
1954\end{array}$ & $\begin{array}{c}\text { Born } \\
1951- \\
1965\end{array}$ & $\begin{array}{c}\text { Born } \\
1940- \\
1954\end{array}$ & $\begin{array}{c}\text { Born } \\
1951- \\
1965\end{array}$ & $\begin{array}{c}\text { Born } \\
1940- \\
1954\end{array}$ & $\begin{array}{c}\text { Born } \\
1951 \\
1965\end{array}$ \\
\hline $\begin{array}{l}\text { Finns, } \\
\text { employment rate }\end{array}$ & 86.9 & 85.3 & 67.1 & 75.5 & 87.7 & 87.3 & 69.6 & 79.8 \\
\hline $\begin{array}{l}\text { Swedes, } \\
\text { employment rate }\end{array}$ & 94.1 & 92.1 & 83.3 & 88.7 & 91.7 & 89.8 & 81.5 & 86.3 \\
\hline $\begin{array}{l}\text { Absolute } \\
\text { difference }\end{array}$ & -7.2 & -6.8 & -16.2 & -13.3 & -4.0 & -2.5 & -11.9 & -6.5 \\
\hline $\begin{array}{l}\text { Percentage } \\
\text { explained by }\end{array}$ & & & & & & & & \\
\hline Age & 0.0 & -3.7 & 3.1 & 0.7 & -0.5 & -10.8 & 0.8 & -4.5 \\
\hline $\begin{array}{l}\text { Educational } \\
\text { level }\end{array}$ & 15.0 & $\underline{10.5}$ & 13.8 & 14.7 & 27.5 & $\underline{34.5}$ & $\underline{18.0}$ & 25.5 \\
\hline County & 5.7 & 4.2 & 1.5 & 0.7 & -2.0 & -2.4 & 0.5 & -0.3 \\
\hline Total & 20.7 & 11.0 & 18.4 & 16.1 & 24.9 & 21.3 & 19.3 & 20.7 \\
\hline
\end{tabular}

Notes: The numbers are for people residing in Sweden both in 1990 and in 2001. A number that is underlined indicates that the variable contributes significantly (at the $5 \%$ level) to explaining the employment differential between Finns and Swedes.

To study the role of these two factors, we additionally performed decompositions across categories of employment experience (yes/no) and immigration year (four groups that best fit the data). The results are summarized in Table 7, where the upper panel is for males and the lower one for females. It shows two main features. Firstly, low education contributes to a substantially higher proportion of the Finnish-Swedish employment gap in people without employment experience than in those with employment experience. Finns with low levels of education, who were unemployed already in 1990, have consequently been specifically vulnerable for changes in the Swedish economy that have occurred during the 1990s. Secondly, time since immigration tends to be positively correlated with employment levels only for males who were employed in 1990. For females and people not employed in 1990, there is no clear pattern in favour of the argument that employment levels are higher for those having arrived earlier. 
TABLE 7A

EMPLOYMENT DIFFERENTIAL BETWEEN FINNS AND SWEDES IN 2001

BY GENDER, BIRTH COHORT, EMPLOYMENT STATUS IN 1990, AND

IMMIGRATION YEAR OF THE FINNS, DECOMPOSITION RESULTS

\begin{tabular}{|c|c|c|c|c|c|c|c|c|}
\hline & \multicolumn{8}{|c|}{ Born 1940-1954 } \\
\hline & \multirow{2}{*}{\multicolumn{4}{|c|}{$\begin{array}{l}\text { Employed in } 1990 \\
\text { Immigration year }\end{array}$}} & \multirow{2}{*}{\multicolumn{4}{|c|}{$\begin{array}{c}\text { Not employed in } 1990 \\
\text { Immigration year }\end{array}$}} \\
\hline & & & & & & & & \\
\hline & -1967 & $68-72$ & $73-80$ & $81-90$ & -1967 & $68-72$ & $73-80$ & $81-90$ \\
\hline \multicolumn{9}{|l|}{ Males } \\
\hline $\begin{array}{l}\text { Finns, } \\
\text { employment rate }\end{array}$ & 76.5 & 73.7 & 70.7 & 61.7 & 23.7 & 23.4 & 21.6 & 21.6 \\
\hline $\begin{array}{l}\text { Swedes, } \\
\text { employment rate }\end{array}$ & 86.2 & 86.2 & 86.2 & 86.2 & 37.8 & 37.8 & 37.8 & 37.8 \\
\hline Absolute difference & -9.7 & -12.4 & -15.5 & -24.5 & -14.1 & -14.4 & -16.2 & -16.2 \\
\hline \multicolumn{9}{|l|}{$\begin{array}{l}\text { Percentage } \\
\text { explained by }\end{array}$} \\
\hline Age & $\underline{23.1}$ & -2.2 & -12.4 & -4.8 & 17.3 & 5.2 & -6.7 & -4.5 \\
\hline Educational level & $\underline{9.8}$ & $\underline{13.7}$ & $\underline{8.0}$ & 4.6 & 21.9 & $\underline{38.9}$ & $\underline{35.9}$ & $\underline{46.1}$ \\
\hline County & -3.0 & -1.0 & 0.2 & -0.2 & -0.1 & -2.0 & -1.6 & -1.3 \\
\hline Total & 29.9 & 10.5 & -4.1 & -0.4 & 39.0 & 42.1 & 27.6 & 40.4 \\
\hline \multicolumn{9}{|l|}{ Females } \\
\hline $\begin{array}{l}\text { Finns, } \\
\text { employment rate }\end{array}$ & 74.5 & 76.4 & 79.5 & 72.1 & 20.6 & 23.3 & 32.3 & 31.0 \\
\hline $\begin{array}{l}\text { Swedes, } \\
\text { employment rate }\end{array}$ & 85.4 & 85.4 & 85.4 & 85.4 & 38.9 & 38.9 & 38.9 & 38.9 \\
\hline Absolute difference & -10.9 & -9.0 & -5.9 & -13.3 & -18.3 & -15.6 & -6.6 & -7.9 \\
\hline \multicolumn{9}{|l|}{$\begin{array}{l}\text { Percentage } \\
\text { explained by }\end{array}$} \\
\hline Age & $\underline{20.0}$ & -16.9 & -42.9 & -12.8 & $\underline{37.1}$ & -2.0 & -62.3 & -25.7 \\
\hline Educational level & $\underline{12.1}$ & $\underline{19.5}$ & 8.8 & 6.2 & 17.7 & $\underline{28.9}$ & 30.6 & 2.2 \\
\hline County & -0.7 & -1.0 & -4.0 & -2.9 & 4.5 & 6.9 & 17.4 & 20.5 \\
\hline Total & 31.4 & 1.6 & -38.2 & -9.5 & 59.3 & 33.9 & -14.3 & -3.1 \\
\hline
\end{tabular}

Notes: The numbers are for people residing in Swe den both in 1990 and in 2001. A number that is underlined indicates that the variable contributes significantly (at the $5 \%$ level) to explaining the employment differential between Finns and Swedes. 
TABLE 7B

EMPLOYMENT DIFFERENTIAL BETWEEN FINNS AND SWEDES IN 2001 BY GENDER, BIRTH COHORT, EMPLOYMENT STATUS IN 1990, AND IMMIGRATION YEAR OF THE FINNS, DECOMPOSITION RESULTS

\begin{tabular}{|c|c|c|c|c|c|c|c|c|}
\hline & \multicolumn{8}{|c|}{ Born 1951-1965 } \\
\hline & \multicolumn{4}{|c|}{$\begin{array}{l}\text { Employed in } 1990 \\
\text { Immigration year }\end{array}$} & \multicolumn{4}{|c|}{$\begin{array}{l}\text { Not employed in } 1990 \\
\text { Immigration year }\end{array}$} \\
\hline & -1967 & $68-72$ & $73-80$ & $81-90$ & -1967 & $68-72$ & $73-80$ & $81-90$ \\
\hline \multicolumn{9}{|l|}{ Males } \\
\hline $\begin{array}{l}\text { Finns, } \\
\text { employment rate }\end{array}$ & 85.7 & 83.3 & 78.3 & 76.7 & 39.8 & 40.3 & 34.5 & 35.3 \\
\hline $\begin{array}{l}\text { Swedes, } \\
\text { employment rate }\end{array}$ & 91.3 & 91.3 & 91.3 & 91.3 & 58.2 & 58.2 & 58.2 & 58.2 \\
\hline Absolute difference & -5.7 & -8.1 & -13.1 & -14.6 & -18.4 & -17.9 & -23.7 & -22.9 \\
\hline \multicolumn{9}{|l|}{$\begin{array}{l}\text { Percentage } \\
\text { explained by }\end{array}$} \\
\hline Age & 0.5 & -0.1 & 1.3 & -0.4 & 14.5 & 6.7 & $\underline{28.3}$ & 8.4 \\
\hline Educational level & $\underline{10.6}$ & $\underline{13.9}$ & $\underline{8.6}$ & 4.9 & 20.9 & $\underline{42.2}$ & $\underline{32.7}$ & $\underline{46.7}$ \\
\hline County & -3.0 & -2.8 & 0.4 & 1.5 & 0.4 & 2.6 & -1.7 & -3.5 \\
\hline Total & 8.1 & 10.9 & 10.3 & 6.0 & 35.9 & 51.6 & 59.3 & 51.7 \\
\hline \multicolumn{9}{|l|}{ Females } \\
\hline $\begin{array}{l}\text { Finns, } \\
\text { employment rate }\end{array}$ & 85.1 & 83.1 & 84.9 & 82.7 & 48.5 & 46.4 & 49.5 & 54.5 \\
\hline $\begin{array}{l}\text { Swedes, } \\
\text { employment rate }\end{array}$ & 89.0 & 89.0 & 89.0 & 89.0 & 62.6 & 62.6 & 62.6 & 62.6 \\
\hline Absolute difference & -3.9 & -5.8 & -4.1 & -6.3 & -14.0 & -16.2 & -13.1 & -8.1 \\
\hline \multicolumn{9}{|l|}{$\begin{array}{l}\text { Percentage } \\
\text { explained by }\end{array}$} \\
\hline Age & -9.5 & -1.2 & -21.6 & 3.8 & 8.8 & 12.1 & 16.8 & -6.2 \\
\hline Educational level & 23.4 & 29.7 & 17.7 & 2.1 & 29.0 & 40.4 & 25.6 & 13.2 \\
\hline County & 2.2 & 0.1 & -0.3 & -0.6 & 7.2 & 4.0 & 1.0 & -0.2 \\
\hline Total & 16.0 & 28.7 & -4.2 & 5.2 & 44.9 & 56.5 & 43.4 & 6.8 \\
\hline
\end{tabular}

Notes: See Table 7A. 
From the table we can also see that, for immigrants having arrived in Sweden between 1968 and 1972, educational level contributes to a higher proportion of the Finnish-Swedish employment gap than in the other immigrant cohorts. For males, the relative employment position of these immigrants is still better than in the later-arrived cohorts.

Not surprisingly, age distribution disfavours Finns who have arrived prior to 1968 , but people in this group still have the best employment position in relation to native Swedes (except for females born 1940-1954). On the other hand, one might have expected that these people should have had an even better situation than that observed here, because they were very young when they immigrated to Sweden, and should be very familiar with the Swedish labour market. Those in birth cohorts between 1951 and 1965, for instance, were all younger than 17 years old when they came to Sweden.

In terms of employment rates, the integration of Finnish immigrants in Sweden is consequently poor in practically all subgroups of the population in prime working ages, albeit being somewhat better in females than in males. The part of the Finnish-Swedish employment gap that can be attributed to educational level, age, and county of residence is also rather small. In the next section we study whether these findings carry over to outcomes among the employed, i.e. to annual earnings.

\section{Earnings differentials}

The approach taken for analysing earnings is very similar to that for employment. We ran separate regressions for log earnings across genders, population groups, and cross section years (results not shown). The results revealed that Swedes had higher returns to education and age than Finns. Earnings variation between people residing in the county of Stockholm and those residing elsewhere also tended to be wider for Swedes than for Finns. In different sociodemographic subgroups there was a fairly consistent male earnings advantage for Swedes, being about the same in magnitude for people aged 36 to 50 years each cross section year. For females, the results were less systematic, as the overall Finnish-Swedish earnings differential was much smaller than for males. For both genders, the earnings gap was largest in people with higher educational levels.

Decomposition results by gender, observation year, and birth cohort are displayed in Table 8 . They show that in both birth cohorts, male Finns earned about 28,000 SEK less than male Swedes. The situation in 1990, of males born between 1951 and 1965, constitutes an exception, as the between-group 
differential here was only 17,000 SEK. In relative numbers, however, the difference is roughly the same, or about 10 per cent. Except for in the group with the lowest absolute earnings differential, differences in educational levels contribute to more than half of the male earnings gap. The negative contribution of county of residence reflects the fact that Finns are overrepresented in the Stockholm area, where overall earnings levels are higher than elsewhere, but that they still suffer in earnings in relation to native Swedes. For females, differences between Finns and Swedes were very small and do not display any obvious pattern. In the next section, where we additionally decompose by immigration year of the Finns, only results for males are displayed (Table 9).

TABLE 8

EARNINGS DIFFERENTIAL BETWEEN FINNS AND SWEDES BY GENDER, OBSERVATION YEAR AND BIRTH COHORT, DECOMPOSITION RESULTS

\begin{tabular}{|c|c|c|c|c|c|c|c|c|}
\hline & \multicolumn{4}{|c|}{ Males } & \multicolumn{4}{|c|}{ Females } \\
\hline & \multicolumn{2}{|c|}{1990} & \multicolumn{2}{|c|}{2001} & \multicolumn{2}{|c|}{1990} & \multicolumn{2}{|c|}{2001} \\
\hline & $\begin{array}{c}\text { Born } \\
1940- \\
1954\end{array}$ & $\begin{array}{c}\text { Born } \\
1951- \\
1965\end{array}$ & $\begin{array}{c}\text { Born } \\
1940- \\
1954\end{array}$ & $\begin{array}{c}\text { Born } \\
1951- \\
1965\end{array}$ & $\begin{array}{c}\text { Born } \\
1940- \\
1954\end{array}$ & $\begin{array}{c}\text { Born } \\
1951- \\
1965\end{array}$ & $\begin{array}{c}\text { Born } \\
1940- \\
1954\end{array}$ & $\begin{array}{c}\text { Born } \\
1951- \\
1965\end{array}$ \\
\hline $\begin{array}{l}\text { Finns, mean } \\
\text { earnings }\end{array}$ & 210.2 & 188.9 & 225.5 & 229.5 & 162.3 & 143.7 & 187.4 & 184.9 \\
\hline $\begin{array}{l}\text { Swedes, mean } \\
\text { earnings }\end{array}$ & 238.5 & 205.9 & 254.1 & 257.4 & 159.1 & 140.6 & 189.7 & 183.1 \\
\hline $\begin{array}{l}\text { Absolute } \\
\text { difference }\end{array}$ & -28.3 & -17.0 & -28.6 & -27.9 & 3.2 & 3.1 & -2.3 & 1.8 \\
\hline $\begin{array}{l}\text { Percentage } \\
\text { explained by }\end{array}$ & & & & & & & & \\
\hline Age & -1.4 & -13.9 & 1.9 & -1.5 & 2.8 & 38.0 & -13.5 & 119.6 \\
\hline $\begin{array}{l}\text { Educational } \\
\text { level }\end{array}$ & $\underline{54.6}$ & $\underline{31.4}$ & $\underline{64.1}$ & $\underline{56.5}$ & -217.7 & -78.1 & 196.9 & -246.0 \\
\hline County & -16.9 & -21.4 & -24.2 & -24.6 & 277.2 & 182.7 & -253.1 & 509.1 \\
\hline Total & 36.3 & -4.0 & 41.7 & 30.4 & 62.3 & 142.7 & -69.8 & 382.7 \\
\hline
\end{tabular}

Notes: Individuals included in estimations are those residing in Sweden both in 1990 and in 2001 with annual earnings above 36,000 SEK each year. Earnings refer to annual earnings in 1,000 SEK. Log of annual earnings have been used in estimations. A number that is underlined indicates that the variable contributes significantly (at the $5 \%$ level) to explaining the earnings differential between Finns and Swedes. 
TABLE 9

EARNINGS DIFFERENTIAL BETWEEN MALE FINNS AND MALE SWEDES BY OBSERVATION YEAR, BIRTH COHORT AND IMMIGRATION YEAR OF THE FINNS, DECOMPOSITION RESULTS

\begin{tabular}{|c|c|c|c|c|c|c|c|c|}
\hline & & $\begin{array}{l}\text { Born } 1 \\
\text { Immigr }\end{array}$ & $\begin{array}{l}40-1954 \\
\text { tion yea }\end{array}$ & & & $\begin{array}{l}\text { Born } 1 \\
\text { Immigr }\end{array}$ & $\begin{array}{l}51-1965 \\
\text { ion yea }\end{array}$ & \\
\hline & -1967 & $68-72$ & $73-80$ & $81-90$ & -1967 & $68-72$ & $73-80$ & $81-90$ \\
\hline 1990 & & & & & & & & \\
\hline $\begin{array}{l}\text { Finns, mean } \\
\text { earnings }\end{array}$ & 222.4 & 208.3 & 196.9 & 177.8 & 197.5 & 188.0 & 188.7 & 168.3 \\
\hline $\begin{array}{l}\text { Swedes, mean } \\
\text { earnings }\end{array}$ & 238.6 & 238.6 & & 238.6 & 205.8 & 205.8 & 205.8 & 205.8 \\
\hline $\begin{array}{l}\text { Absolute difference } \\
\text { Percentage } \\
\text { explained by }\end{array}$ & -16.2 & -30.3 & -41.7 & -60.7 & -8.3 & -17.8 & -17.2 & -37.6 \\
\hline Age & -12.0 & -3.5 & $\underline{8.2}$ & 3.4 & -30.8 & 11.2 & -48.0 & 5.5 \\
\hline Educational level & $\underline{71.8}$ & $\underline{71.2}$ & $\underline{36.5}$ & 23.2 & $\underline{36.2}$ & $\underline{36.0}$ & $\underline{42.3}$ & 14.1 \\
\hline County & -25.5 & -15.5 & -16.9 & -13.2 & -30.2 & -15.5 & -32.8 & -17.4 \\
\hline Total & 34.3 & 52.2 & 27.8 & 13.4 & -24.8 & 31.7 & -38.5 & 2.2 \\
\hline 2001 & & & & & & & & \\
\hline $\begin{array}{l}\text { Finns, mean } \\
\text { earnings }\end{array}$ & 233.3 & 221.3 & 217.6 & 212.1 & 240.3 & 226.5 & 223.0 & 217.8 \\
\hline $\begin{array}{l}\text { Swedes, mean } \\
\text { earnings }\end{array}$ & 254.1 & 254.1 & 254.1 & 254.1 & 257.4 & & 257.4 & 257.4 \\
\hline $\begin{array}{l}\text { Absolute difference } \\
\text { Percentage } \\
\text { explained by }\end{array}$ & -20.8 & -32.8 & -36.5 & -42.0 & -17.1 & -30.9 & -34.4 & -39.6 \\
\hline Age & 17.8 & -4.1 & -9.5 & -5.6 & -3.4 & 1.8 & -4.3 & 0.7 \\
\hline Educational level & $\underline{64.7}$ & $\underline{83.0}$ & $\underline{48.1}$ & $\underline{27.6}$ & $\underline{66.0}$ & $\underline{69.1}$ & $\underline{56.5}$ & $\underline{24.9}$ \\
\hline County & -27.6 & -20.4 & -29.4 & -28.1 & -24.4 & -15.2 & -31.2 & -35.0 \\
\hline Total & 54.8 & 58.6 & 9.2 & -6.0 & 38.2 & 55.7 & 21.0 & -9.4 \\
\hline
\end{tabular}

Notes: Individuals included in estimations are males residing in Sweden both in 1990 and in 2001, with annual earnings above 36,000 SEK each year. Earnings refer to annual earnings in 1,000 SEK. Log of annual earnings have been used in estimations. A number that is underlined indicates that the variable contributes significantly (at the $5 \%$ level) to explaining the earnings differential between Finns and Swedes. 
Year of immigration turns out to play an important role for the Finnish-Swedish earnings gap, as Finns having arrived earlier perform substantially better than those having arrived later (Table 9). In the early immigrant cohorts, and in 2001, the contribution of educational level on the earnings gap is specifically large. Within the same educational levels (disregarding differences in distribution of age and county of residence), Finnish males who have immigrated before 1968, say, had only about 5,000 SEK lower earnings than native Swedes. ${ }^{8}$ In the other three immigrant cohorts the earnings gap was wider, and those having immigrated between 1981 and 1990 had specifically low relative wages. Age distribution naturally varies greatly between immigrants having arrived in different years, but age does not contribute to the Finnish-Swedish earnings differential to any noteworthy degree.

Finally, we decompose the Finnish-Swedish differential in earnings mobility, i.e. in the change of earnings between 1990 and 2001. ${ }^{9}$ The results are found in Table 10, which shows that the development has been specifically in favour of male Swedes in the younger birth cohort, but the great part, or more than twothirds, of their better performance is explained by higher educational levels. The results also reflect that earnings mobility has been specifically strong among Swedes living in the Stockholm area. For females, the difference in earnings mobility between Finns and Swedes is low and the decomposition results rather ambiguous.

Table 11, which additionally gives results by immigration year for males, reveals that the relative earnings mobility of Finnish males has had a tendency to be higher in the earlier immigrant cohorts than in later ones. Still, it seems to have been highest in those having arrived between 1981 and 1990, and for those born 1940 to 1954 even higher than of native Swedes. This group amounts to only 5 per cent of all Finnish immigrants in the birth cohort, however.

The overall picture is, therefore, that male Finnish immigrants in Sweden perform substantially worse than their Swedish counterparts with respect to both earnings levels and earnings mobility, but also that a substantial part of this gap is interrelated with generally lower educational levels.

\section{CONCLUSIONS}

This paper has shown that it is by no means a matter of cause that an immigrant population will assimilate towards native labour market positions even if there is close social and cultural proximity, or if the countries involved have a long history of free migration of labour. One possible cause for this scenario is that 
immigrant labour to a greater extent than native labour enters sectors of the host country labour market that are sensitive to macroeconomic shocks (see Bevelander, 1995; Scott, 1999; Bevelander and Skyt Nielsen, 2001). In an economic upheaval, the demand for labour in these sectors is expected to be higher than in other sectors, whereas the opposite is the case during an economic downturn. Together with strict regulations on hiring and firing that exist in Sweden ("last in is first out"), this is likely to impact severely on the outcomes of immigrants. These arguments tend to be supported by the present results in the sense that immigrants' relative performance seems to have improved with time spent in Sweden, i.e. with increasing possibilities to adjust to specific features and structural changes in the host country.

TABLE 10

DIFFERENCE IN INDIVIDUAL EARNINGS MOBILITY BETWEEN FINNS AND SWEDES BY GENDER AND BIRTH COHORT, DECOMPOSITION RESULTS

\begin{tabular}{|c|c|c|c|c|}
\hline & \multicolumn{2}{|c|}{ Males } & \multicolumn{2}{|c|}{ Females } \\
\hline & $\begin{array}{c}\text { Born } \\
1940-1954\end{array}$ & $\begin{array}{c}\text { Born } \\
1951-1965\end{array}$ & $\begin{array}{c}\text { Born } \\
1940-1954\end{array}$ & $\begin{array}{c}\text { Born } \\
1951-1965\end{array}$ \\
\hline $\begin{array}{l}\text { Finns, mean } \\
\text { earnings change }\end{array}$ & 15.0 & 45.9 & 28.6 & 48.9 \\
\hline $\begin{array}{l}\text { Swedes, mean } \\
\text { earnings change }\end{array}$ & 27.7 & 69.4 & 35.7 & 51.9 \\
\hline $\begin{array}{l}\text { Difference in means } \\
\text { Percentage } \\
\text { explained by }\end{array}$ & -12.7 & -23.5 & -7.1 & -3.0 \\
\hline Age & 8.1 & 7.5 & -7.4 & -30.4 \\
\hline Educational level & 68.2 & 67.9 & 34.6 & 100.3 \\
\hline County & -32.2 & -28.9 & -23.6 & -115.2 \\
\hline Total & 44.1 & 46.5 & 3.6 & -45.3 \\
\hline
\end{tabular}

Notes: Individuals included in estimations are those residing in Sweden both in 1990 and in 2001, with annual earnings above 36,000 SEK both years. Earnings mobility refers to absolute change in annual earnings between 1990 and 2001. A number that is underlined indicates that the variable contributes significantly (at the $5 \%$ level) to explaining the differential in earnings mobility between Finns and Swedes. 
TABLE 11

DIFFERENCE IN INDIVI DUAL EARNINGS MOBILITY BETWEEN MALE FINNS AND MALE SWEDES BY BIRTH COHORT AND IMMIGRANT YEAR OF THE FINNS, DECOMPOSITION RESULTS

\begin{tabular}{|c|c|c|c|c|c|c|c|c|}
\hline & \multicolumn{4}{|c|}{$\begin{array}{l}\text { Born 1940-1954 } \\
\text { Immigration year }\end{array}$} & \multicolumn{4}{|c|}{$\begin{array}{l}\text { Born 1951-1965 } \\
\text { Immigration year }\end{array}$} \\
\hline & -1967 & $68-72$ & $73-80$ & $81-90$ & -1967 & $68-72$ & $73-80$ & $81-90$ \\
\hline $\begin{array}{l}\text { Finns, mean } \\
\text { earnings change }\end{array}$ & 13.6 & 11.5 & 18.4 & 37.5 & 50.9 & 41.1 & 34.7 & 64.5 \\
\hline $\begin{array}{l}\text { Swedes, mean } \\
\text { earnings change }\end{array}$ & 27.7 & 27.7 & 27.7 & 27.7 & 69.4 & 69.4 & 69.4 & 69.4 \\
\hline $\begin{array}{l}\text { Difference in } \\
\text { means }\end{array}$ & -14.2 & -16.2 & -9.3 & 9.7 & -18.5 & -28.3 & -34.7 & -4.9 \\
\hline $\begin{array}{l}\text { Percentage } \\
\text { explained by }\end{array}$ & & & & & & & & \\
\hline Age & $\underline{45.1}$ & -0.4 & -94.4 & 59.4 & 10.2 & -5.7 & $\underline{19.9}$ & -51.6 \\
\hline Educational level & $\underline{50.4}$ & 78.4 & 78.0 & -46.0 & $\underline{68.6}$ & 78.7 & 53.5 & 150.6 \\
\hline County & -26.7 & -25.1 & -55.0 & 58.1 & -20.3 & -15.5 & -31.7 & -264.2 \\
\hline Total & 68.8 & 52.9 & -71.4 & 71.5 & 58.5 & 57.5 & 41.7 & -165.2 \\
\hline
\end{tabular}

Notes: Individuals included in estimations are males residing in Sweden both in 1990 and in 2001, with annual earnings above 36,000 SEK both years. Earnings mobility refers to absolute change in annual earnings between 1990 and 2001. A number that is underlined indicates that the variable contributes significantly (at the $5 \%$ level) to explaining the differential in earnings mobility between Finns and Swedes.

In spite of 50 years of free labour mobility in the Nordic countries and labour market institutions that resemble each other greatly, the integration of the largest group of immigrants in Sweden is consequently a story that is far from successful. Finns in Sweden have lower employment rates and lower earnings than native Swedes, and the situation seems to have worsened in line with the economic downturn in the 1990s. There is substantial gender variation in this context, however. Finnish males have earnings and employment rates that are about 10 per cent less than Swedish males, but for females the employment gap is only half that of males and with respect to earnings there is practically no between-group differential.

Differences in educational levels, age distribution, and county of residence can to a fairly limited extent explain the employment differential, but more than half of the gap in male earnings and male earnings mobility can be attributed to educational differences. It should be pointed out, though, that Finns do not 
benefit from being geographically concentrated in the Stockholm area, where earnings levels are markedly higher than elsewhere.

Finnish females consequently seem to be better integrated in the Swedish labour market than Finnish males. This finding corresponds with the situation in the 1970s and 1980s, and therefore suggests that they have managed to maintain their relatively good labour market position. One way of explaining these findings is in terms of how Finnish males and Finnish females differ in occupational distribution as compared with their Swedish counterparts. Official statistics tell us that Finnish females work in fairly similar occupations as Swedish females, whereas Finnish males to a much higher extent than Swedish males are found in non-managerial occupations and occupations that do not require academic and specialized competence. Thus, given that the industrial sector has lost ground between 1990 and 2001, this may potentially also underlie the decline in the relative position of Finnish males.

From the international literature it is known that earnings losses and reemployment probabilities caused by macroeconomic shocks may vary greatly across genders and population groups. The reasons as to why layoffs and plant closings affect demographic groups differently are not yet fully understood, however, although it has been suggested that asymmetric information, statistical discrimination, heterogeneous human capital and taste discrimination might underlie the findings (see e.g. $\mathrm{Hu}$ and Taber, 2005). It is plausible that such explanations could be important also in the present case.

Still, it ought to be borne in mind that there is great diversity also within the immigrant population studied here, and that the number of control variables used to account for such heterogeneity has been relatively few. A person's family situation, and (previous) industry of work, for instance, may tell us something more about variation in labour market position.

Another issue worthy of note is that approximately one-quarter of the Finnish immigrant population in Sweden has Swedish as their mother tongue (Finnäs, 1986; Leiniö, 1984), as they originate from the Swedish-speaking coastal areas of Finland. Analyses based on survey data from the early 1980s (Leiniö, 1984) indicate that these Swedish-speaking Finns in many respects perform better than Finnish-speaking Finns in the Swedish labour market. Recent studies conducted with register-based data from Finland show that the two groups tend to differ in a similar respect also in the Finnish labour market (Saarela and Finnäs, 2002, 2003, 2004, 2006). In addition, those results support the present ones in the context that the between-group variation in outcomes is larger in males than in females. The poor labour market situation of Finnish immigrants in Sweden 
found here may consequently be an underestimate of difficulties experienced by people with Finnish as their mother tongue. Unfortunately, Swedish register data do not contain information about people's mother tongue. Separating the two groups is therefore accomplishable only by matching register data from Sweden and Finland. Still, that seems to be a gainful avenue for further understanding of immigrants' integration in countries with long traditions of free labour mobility.

\section{NOTES}

1. Comments from Fjalar Finnäs, two anonymous referees, and seminar participants at the Turku Center for Welfare Research have been helpful. Jan Saarela gratefully acknowledges financial support from Åbo Akademis Jubileumsfond 1968 and Letterstedtska föreningen, and Dan-Olof Rooth from the Swedish Council for Working Life and Social Research.

2. References on this point are numerous, starting from Chiswick $(1978,1982)$ and Borjas $(1984,1985,1987,1989)$, followed by research conducted by, for instance, LaLonde and Topel (1991), Pischke (1992), Dustmann (1993), Blackaby et al. (1994), Kee (1994), Borjas (1995), Funkhouser and Trejo (1995), Chiswick and Hurst (1996), Chiswick et al. (1997), and Schmidt (1997).

3. Labour market outcomes of second-generation immigrants in Sweden have been studied by Rooth and Ekberg (2003).

4. Approximately 15 per cent of those under study were younger than 16 years of age when they arrived in Sweden.

5. Methods of performing decomposition that use estimates from non-linear models have been developed, however (Fairlie, 1999, 2003).

6. Migration may still be selective if those who decide to stay permanently initially were planning to stay only temporarily (or vice versa), or if emigrants from Finland constitute a non-random group of the Finnish population. Additionally, it is plausible that some people under analysis may have migrated back to Sweden after having returned to Finland between 1990 and 2001.

7. Since "year of immigration" refers to the most recent year of immigration it is an underestimate for time spent in Sweden for frequent migrants. As we focus on people who resided in Sweden both in 1990 and in 2001, the group of frequent migrants should be small, however.

8. This is $-16.2 \times(1-0.718)$ for birth cohort 1940-1954 in 1990, $-8.3 \times(1-0.362)$ for birth cohort 1951-1965 in 1990, -20.8 $\times(1-0.647)$ for birth cohort 1940-1954 in 2001, and $-17.1 \times(1-0.660)$ for birth cohort 1951-1965 in 2001.

9. This could be interpreted as partially controlling for unobserved heterogeneity in the sense that time-invariant unobserved heterogeneity may be captured by the individual's earnings in 1990 (see Cobb-Clark and Crossley, 2003). 


\section{REFERENCES}

Aguilar, R., and B. Gustafsson

1991 "The earnings assimilation of immigrants", Labour, 5: 37-51.

Antelius, J., and A. Björklund

2000 "How reliable are register data for studies of the return on schooling? An examination of Swedish data", Scandinavian Journal of Educational Research, 44: 341-355.

Bantekas, A.

1992 Three Essays on Discrimination and Factor Demand, Doctoral dissertation, Department of Economics, Uppsala University.

Bevelander, P.

1995 Labour Force Participation of Immigrants in Sweden 1960-1990, Licentiate thesis, Department of Economic History, University of Lund.

Bevelander, P., and H. Skyt Nielsen

2001 "Declining employment assimilation of immigrants in Sweden: observed or unobserved characteristics?", Journal of Population Economics, 14: 455-471.

Blackaby, D., et al.

1994 "Black-white male earnings and employment prospects in the 1970s and 1980s: Evidence for Britain", Economic Letters, 46: 273-279.

Borjas, G. J.

1984 "The economic status of male Hispanic migrants and natives in the United States", in R.G. Ehrenberg (Ed.), Research in Labour Economics, A.I. Press, Greenwich, Connecticut: 65-122.

1985 "Assimilation, changes in cohort quality, and the earnings of immigrants", Journal of Labour Economics, 3: 463-489.

1987 "Self-selection and the earnings of immigrants", American Economic Review, 77: 531-553.

1989 "Immigrant and emigrant earnings: a longitudinal study", Economic Inquiry, 27: 21-37.

1994 "The economics of immigration", Journal of Economic Literature, 32: 1667-1717.

1995 "Assimilation and changes in cohort quality revisited: what happened to immigrant earnings in the 1980s?", Journal of Labour Economics, 13: 177-201.

Chiswick, B.

1978 "The effect of Americanization on the earnings of foreign-born men", Journal of Political Economy, 86: 897-921.

1982 The Employment of Immigrants in the United States. American Enterprise Institute, Washington D.C.

Chiswick, B., and M. Hurst

1996 "The employment, unemployment, and unemployment compensation benefits of immigrants", Research in Employment Policy, 1. 
Chiswick, B., et al.

1997 "The labor market status of immigrants: effects of the unemployment rate at arrival and duration of residence", Industrial and Labor Relations Review, 50: 289-303.

Cobb-Clark, D.A., and T. Crossley

2003 "Econometrics for evaluations: an introduction to recent developments", Economic Record, 79: 491-511.

Dustmann, C.

1993 "Earnings adjustment of temporary migrants", Journal of Population Economics, 6: 153-168.

2000 "Temporary migration and economic assimilation", Swedish Economic Policy Review, 7: 213-244.

Dustmann, C., and F. Fabbri

2003 "Language proficiency and labour market performance of immigrants in the UK", Economic Journal, 113: 695-717.

Edin, P.-A., et al.

2000 "Emigration of immigrants and measures of immigrant assimilation: evidence from Sweden", Swedish Economic Policy Review, 7: 163-204.

Ekberg, J.

1983 Inkomsteffekter av invandring, Doctoral dissertation, Department of Economics, University of Lund.

1991 "Vad hände sedan? En studie av utrikes födda på arbetsmarknaden", Acta Wexionensia, Serie 2, Economy and Politics 3, Högskolan i Växjö.

1994 "Economic progress of immigrants in Sweden from 1970 to 1990: a longitudinal study", Scandinavian Journal of Social Welfare, 3: 148-157.

1996 "Invandrarna i pensionssystemet", Socialvetenskaplig Tidskrift, 3: 243-255.

2004 "Systemfel i politiken", in Egenförsörjning eller bidragsförsörjning? Invandrarna, arbetsmarknaden och välfärdsstaten, SOU 2004:21, Elanders Gotab AB, Stockholm: 281-291.

Ekberg, J., and L. Andersson

1995 Invandring, sysselsättning och ekonomiska effekter, DS 1995:68, Fritzes förlag, Stockholm.

Fairlie, R.W.

1999 "The absence of the African-American owned business: an analysis of the dynamics of self-employment", Journal of Labor Economics, 17: 80-108.

2003 "An extension of the Blinder-Oaxaca decomposition technique to logit and probit models", Center Discussion Paper, 873, Economic Growth Center, Yale University.

Finnäs, F.

1986 Den finlandssvenska befolkningsutvecklingen 1950-1980. En analys av en språkgrupps demografiska utveckling och effekten av blandäktenskap, Doctoral dissertation, Skrifter utgivna av svenska litteratursällskapet i Finland, Nr. 533, Svenska litteratursällskapet i Finland, Helsingfors. 
2003 "Migration and return migration among Swedish-speaking Finns", in R. Höglund et al. (Eds), Statistics, Econometrics and Society: Essays in Honour of Leif Nordberg, Research Reports, 238, Statistics Finland, Helsinki: 41-54.

Funkhouser, E., and S. Trejo

1995 "The labour market skills of recent male immigrants: evidence from the current population survey", Industrial and Labour Relations Review, 48: 792-811.

Gustafsson, B., and T. Österberg

2004 "Ursprung och förtidspension", in Egenförsörjning eller bidragsförsörjning? Invandrarna, arbetsmarknaden och välfärdsstaten, SOU 2004:21, Elanders Gotab AB, Stockholm: 57-102.

Gustafsson, B., et al.

2004 "Invandrares arbetsmarknadssituation - översikt och nya siffror", in Egenförsörjning eller bidragsförsörjning? Invandrarna, arbetsmarknaden och välfärdsstaten, SOU 2004:21, Elanders Gotab AB, Stockholm: 15-55.

Hedberg, C., and K. Kepsu

2003 "Migration as a cultural expression? The case of the Finland-Swedish minority's migration to Sweden", Geografiska Annaler, 85B: 67-84.

$\mathrm{Hu}, \mathrm{L}$. , and C. Taber

2005 "Layoffs, lemons, race and gender", IZA Discussion Paper, 1702, IZA, Bonn.

Institute of Migration

2004 "Maahan: ja maastamuuttaneet vuosina 1945-2002", http://www. migrationinstitute.fi/db/stat/fin/art.php?artid=4.

Kee, P.

1994 "Native-immigrant employment differentials in the Netherlands: the role of assimilation and discrimination", International Review of Applied Economics, 8: 174-196.

Korkiasaari, J., and I. Söderling

1998 "Finland: from a country of emigration into a country of immigration", in

I. Söderling (Ed.), A Changing Pattern of Migration in Finland and Its Surroundings, Publications of the Population Research Institute, D 32, Population Research Institute, Helsinki.

LaLonde, R., and R. Topel

1991 "Immigrants in the American labour market: quality, assimilation, and distributional effects", American Economic Review: Papers and Proceedings, 81: 297-302.

Leiniö, T.-L.

1979 "Finska invandrare i Sverige 1974. Levnadsnivåprojektet”, Rapport nr 3, Swedish Institute for Social Research, Stockholm University.

1984 "Inte lika men jämlika? Om finländska invandrares levnadsförhållanden enligt levnadsnivåundersökningarna 1968, 1974 och 1981”, 1981 års levnadsnivåundersökning, Rapport nr 6, Swedish Institute for Social Research, Stockholm University. 
Neumark, D.

1988 "Employers' discriminatory behaviour and the estimation of wage discrimination", Journal of Human Resources, 23: 279-295.

Oaxaca, R., and M.R. Ransom

1994 "On discrimination and the decomposition of wage differentials", Journal of Econometrics, 61: 5-21.

Ohlsson, R.

1975 Invandrarna på arbetsmarknaden, Doctoral dissertation, Department of Economic History, University of Lund.

Pekkari, A.

2000 "Arbetskraft, sysselsättning, arbetslöshet mm - utvecklingen under 1990talet”, Ura 2000:2, Arbetsmarknadsstyrelsen, Stockholm.

Pischke, J.

1992 "Assimilation and the earnings of guestworkers in Germany", ZEW Discussion Paper, 92:17, ZEW, Mannheim.

Rooth, D.-O., and J. Ekberg

2003 "Unemployment and earnings for second generation immigrants in Sweden: ethnic background and parent composition", Journal of Population Economics, 16: 787-814.

Saarela, J., and F. Finnäs

2002 "Language-group differences in very early retirement in Finland", Demographic Research, 7: 49-66.

2003 "Unemployment and native language: the Finnish case", Journal of SocioEconomics, 32: 59-80.

2004 "Interethnic wage variation in the Helsinki area", Finnish Economic Papers, 17: 35-48.

2006 "Can the low unemployment rate of Swedish speakers in Finland be attributed to structural factors?", Journal of Socio-Economics, 35: 498-513.

Schmidt, C.

1997 "Immigrant performance in Germany: labor earnings of ethnic German migrants and foreign guest workers", Quarterly Review of Economics and Finance, 37: 379-397.

Scott, K.

1999 The Immigrant Experience: Changing Employment and Income Patterns in Sweden, 1970-1993, Doctoral dissertation, Department of Economic History, University of Lund.

Statistics Sweden

2002 "Integration till svensk välfärd? Om invandrares välfärd på 90-talet", Living Conditions, 96, The National Institute for Working Life, Statistics Sweden, Stockholm.

2003 "Population Statistics 2002 according to the Administrative Subdivisions of Jan. 1, 2003", Official Statistics of Sweden, Part 3, Distribution by Sex, Age, Country of Birth etc., Statistics Sweden, Örebro.

2004 "Sysselsättning och arbetslöshet 1975-2003", Information för Arbetskraftsundersökningarna 2004:1, Statistics Sweden, Stockholm. 
Wadensjö, E.

1973 Immigration och samhällsekonomi, Doctoral dissertation, Department of Economics, University of Lund.

1994 "The earnings of immigrants in Sweden", paper presented at EALE 1994, Warsaw. 


\section{DANS QUELLE MESURE LES FINLANDAIS SONT-ILS INTÉGRÉS AU MARCHÉ DU TRAVAIL SUÉDOIS ? RÉSULTATS DE LA LIBRE MOBILITÉ DE LA MAIN-D’EUVRE}

En raison d'un accord instituant un marché commun nordique du travail, les Finlandais constituent, depuis des décennies, le plus grand groupe d'immigrés en Suède. Pourtant, rares sont les études qui ont spécifiquement tenté de déterminer dans quelle mesure ils sont intégrés au marché du travail. Cet article vise à combler en partie cette lacune en examinant comment les Finlandais ont réussi avant et après la crise économique des années 90. Les niveaux d'emploi et les salaires des immigrés finlandais dans la force de l'âge sont comparés à ceux des Suédois de souche à l'aide d'échantillons représentatifs de la population totale de 1990 et 2001. Nous cherchons à déterminer dans quelle mesure tout écart peut être attribué à de simples facteurs de base tels que l'âge, le sexe, le niveau d'éducation et la région de résidence. D'après nos constatations, les salaires et niveaux d'emploi des Finlandais de sexe masculin sont environ $10 \%$ moins élevés que ceux des Suédois de souche et cet écart tend à devenir plus marqué au fil du temps. Il existe toutefois des variations considérables entre les cohortes d'immigrés, et les différences de niveaux d'éducation ne jouent un rôle significatif qu'en ce qui concerne les écarts de salaire. Les Finlandaises semblent en revanche mieux intégrées, leurs résultats sur le marché du travail étant très semblables à ceux des Suédoises de souche. 


\section{¿EN QUÉ MEDIDA ESTÁN LOS FINLANDESES INTEGRADOS EN EL MERCADO LABORAL SUECO? RESULTADOS DE LA LIBERTAD DE MOVILIDAD LABORAL}

Debido al acuerdo en virtud del cual se creó un mercado laboral nórdico común, los finlandeses llevan décadas constituyendo el principal grupo de inmigrantes de Suecia. Sin embargo, hay pocos estudios dedicados explícitamente a analizar en qué medida están integrados en el mercado laboral. Este artículo trata de cubrir parte de esa laguna estudiando cómo salieron adelante antes y después de la crisis económica de la década de los noventa. Se comparan los niveles de empleo y los ingresos de los inmigrantes finlandeses de los grupos etarios más activos con los de los suecos nativos, utilizando muestras representativas emparejadas de la población total de 1990 y 2001. El objetivo es comprobar qué parte de cualquier diferencial puede atribuirse a factores de partida como la edad, el sexo, el nivel educativo y el país de residencia. Nuestras averiguaciones revelan que los ingresos y los niveles de empleo de los varones finlandeses son aproximadamente un 10 por ciento más bajos que los de los suecos autóctonos y que esa brecha tiende a agrandarse con el tiempo. Existen, sin embargo, sustanciales variaciones entre grupos de inmigrantes y las diferencias de nivel educativo sólo tienen un papel significativo en relación con la distancia en los ingresos. En comparación con los varones, las mujeres finlandesas tienden a estar mejor integradas y los resultados sobre mercado laboral son muy similares a los de las suecas autóctonas. 